\title{
Review: Rivera, Iñaki. Decarceration, principles for a public policy of reduction of the prison reduction (from a radical guarantism), Valencia: Tirant lo Blanch, 2017, 252 p.
}

\author{
Resenha: Rivera, Iñaki. Descarcelación, principios para una política \\ pública de reducción de la cárcel (desde un garantismo radical). \\ Valencia: Tirant lo Blanch, 2017, 252 p.
}

\section{Silvio Cuneo ${ }^{1}$}

Universidad Central de Chile silvio.cuneo@ucentral.cl http://orcid.org/0000-0003-1072-745X

Following a coherent line of research expounded in a number of various previous publications on prison, Iñaki Rivera, in this latest work presents a realistic and necessary picture of a possible road to mass decarceration. Together with undertaking a comprehensive social and juridical analysis of the complex world of prison and incarceration, the author does not lose sight of the essential aspect, the human being, the unique and exclusive individual who suffers physically and spiritually the brutality of punitive power: he who, from his solitary and silent or overcrowded and noisy cell, feels that his life is not worth living.

The book firmly asserts that the problem of prison must be solved by first seeing to the needs of the inmates themselves, reminding us that the issue of prison cannot continue to be addressed without its main protagonists, it cannot continue to be examined (only) by "experts". However, it recognises

1 Profesor y Coordinador del Centro de Investigaciones Criminológicas de la Justicia Penal de la Universidad Central de Chil. Doctor en Derecho por la Universitat Pompeu Fabra y la Università degli Studi di Trento. Entre sus libros destacan: “Cárceles y pobreza. Distorsiones del populismo penal” (2018), "El encarcelamiento masivo" (2017), "La cárcel moderna. Una crítica necesaria” (2017) y "Cine y Derecho penal” (2010). 
that this problem will hardly be solved inside the prison itself, but rather outside of it, in the same society that creates it, produces it, feeds it and reproduces it. In this light, the best option will never be to "improve" such a savage and violent institution as prison, but to think less and less in terms of prison itself, primarily looking for strategies to contain the influx of new inmates, then its reduction, and finally its radical elimination.

Although it might appear obvious, the book reminds us that not because things stands as they are, they should be like that. Slavery, poverty, social injustice and exploitation, as well as mass and inhuman imprisonment, are not natural phenomena: they are created by society and can and must be changed. Even if something seems unfeasible (for example, the end of discrimination against women or the thousands of daily child deaths from poverty-related causes) this makes it no less morally desirable.

Essentially (although it may not be explicitly acknowledged by the author), it is a juridical-criminal analysis that involves sociological matters and the philosophy of punishment. The author positions his premises of excarceration in a non-static point somewhere between abolitionism and liberal theory of criminal law, leaning towards the latter in order to opt for a possible and necessary path, distancing itself from abolitionist ideals. Rivera's work in this aspect recalls the words of Manuel de Rivacoba who criticised abolition - albeit acknowledging the noble impulses of these aspirations -while reminding us that "unless there is a transmutation in human nature and, consequently, in social demands and institutions, abolition itself is not, as in Stammler's wellknown simile, a polar star for sailors, a port to reach and disembark, but it is rather a brilliant idea that is both a guide and a destination which we relentlessly strive to reach, a regulating principle, meaning, a model determining the degree of perfection, that is to say of effectiveness, of different punitive legislation. On the hand, believing it to be attainable and striving to achieve it or accomplish it in our times may well distract our attention and efforts from more urgent and feasible tasks; including fully knowing and rationally applying existing Law, undertaking or continuing a serious and steady process of decriminalisation or advancing along the path of humanisation. Or in other words: what is desirable must not thwart or lead us astray from what is possible; the maximalist aspiration 
to the absolute must not frustrate our efforts towards obtaining a truly minimal, sustainable, dignified criminal law". ${ }^{2}$

I would like to stress that this work is a juridical - criminal analysis focusing on the dark and forsaken world of prison conviction. Criminal law, it should be remembered, is a two-faced coin (crimes and punishments, Cesare Beccaria told us just over 250 years ago). However, it seems that criminal lawyers have forgotten about punishment, and in their manuals, treaties, monographs, etc. they dedicate themselves almost exclusively to the analysis of the theory of crime, more and more abstractly, from up high, omitting almost any kind of reference to the world of punishment. Several professors of criminal law fail to lower themselves to the reality of the sentence, ignorant of prisons, and their silence ends up legitimising this space which is a legislative void or a negation of Rights. In this way, prison expands without losing its aspect of a space devoid of justice, forgotten by the criminal lawyers. This book, on the contrary, invites us to enter the world of prison, and perhaps even more importantly, it calls for the opening up of prison, so that prison itself becomes less prison (quantitatively and qualitatively) and is understood as part of a society that must respect the human rights of all people, whether they be free or imprisoned.

Iñaki Rivera's book does not lose sight, like the polar star, of the concept of the individual. It also reminds us that since the International Human Rights Law, there has been a globally recognized idea of the individual, established in international covenants - concerning penal issues, criminal procedure and prison, and especially in the Universal Declaration of Human Rights which places limits on state interference or behaviour and compels us not to exploit our fellow humans. These agreements integrate the legal systems, within which they are made a priority. As such, legislation, regulations and official practices must therefore be brought in line with them. All of the legal system must be consistent with itself, logically and axiologically. A conception of prison is also to have a conception of the penalty and a conception of the penalty is to have that of the human being.

2 RIVACOBA, Manuel de, Función y aplicación de la pena, Depalma, Buenos Aires, 1993, p. XII 
Rivera exposes the fallacies of arguments legitimising prison, particularly the positivity of prevention fallacy (the rhetoric of rehabilitation) based on the idea that it is possible to teach people to live in freedom by depriving convicts of their freedom. Likewise, the book harshly criticises authoritarian conceptions of criminal law by eminent personages that, rather than prosecute specific deeds, punish personalities and ways of being, labelling convicts and ascribing them future behaviour based on the illusion of being able to foresee risks. On the other hand the book also is strongly critical of penetrating conceptions that contain and foment a declared hostility towards he who is increasingly seen as the "other", someone different who can acquire monstrous morphologies (terrorist, paedophile or serial killer), but who is usually an ugly, dirty and bad common criminal (paraphrasing a film by Ettore Scola). Alarmist concepts encourage the control and confinement of enemies, convincing us that our security depends on their control.

Rivera reminds us according to this conception, politics assumes the characteristic feature of conflict since any divergence of interests can at some point be transformed into rivalry or antagonism between people or social groups. Such arguments obtain enormous electoral consensus for politicians who promise the massive confinement of enemies of public order. To legitimise these bellicose, antiliberal and antidemocratic policies, pseudo criminologists appear who, with scientific semblance, echo social demands (previously inflamed by disproportionate fear), and opinionists, masquerading as specialists, set up centres of "study" flanking political spheres that hold power (for example, the Manhattan Institute in the United States, the Fundación Paz Ciudadana in Chile, etc.) creating a distorted image of criminality where the common criminal (read poor and marginal) is an enemy undeserving of any rights, who must be imprisoned.

Rivera also looks with distrust at the so-called alternative forms to prison, since these exist alongside prison. For these, prison still maintains a central role and the so-called alternatives are in need of prison in order to operate. In the same way, experience teaches us - or should teach us that the implementation of alternative sentences to prison often does not translate in a reduction in prison sentences, but only in an expansion of the punitive network. 
As for the actual carrying out of the custodial sentence, Rivera denounces prison within the prison, an implementation that does not respect the principle of legality (nor those of proportionality, guilt, offensiveness, certainty, concreteness and humanity), operating with a high discretionary power based on the assessment of the personality of the detainee. It is, in Ferrajoli's words, a substantially arbitrary and antiliberal power that contradicts the founding principle of guaranteeing the criminal's rights according to which you cannot be punished for what you are, but for what you have done.

After analysing the multi and devastating effects prison produces on those who experience it, Riviera, on citing Gonin and Pavarini, confines prison's history in the broader history of hypocrisy. Prison is no more humane than the atrocious public penalties that went before it in history. The main difference has not so much to do with the respect or the dignity of the prisoner as it has with the sensitivity of a society that preferred not to witness human suffering. Thus, prison conceals suffering within four walls. Therefore, the pain of convicts, although known, can be ignored. We are all aware of what occurs inside prison and we seem to accept it without further questioning; however, at the same time we deny the fact. We cannot conceive that our prisons are only for the poor and that they constitute only a system of oppression for people to whom we have denied education, health and housing.

Stanley Cohen coined the concept of a state of denial, according to which people are familiar and are not familiar at the same time with a certain phenomenon. Today we know and we do not know that prison is an inhuman space. We know that every year a high number of poor people will be imprisoned, and we know as well that they could die, be injured, be raped by other inmates or tortured by police officers. However, since we know that prisoners are from slums and that they behave in a way exactly opposite to us, we do not care. Somehow, we believe that they deserve what they are experiencing or that they are predestined to it, but if we question what they deserve in relation to what we have given them and what we demand of them, we know (or we do not know) that they do not deserve all the injustices they are forced to live (hunger, lack of opportunities, lack of decent housing and basic necessities, impossibility to go to university, high probability of ending up in prison, etc.). Prison 
is inhuman; however, the denial of prison's reality is easy because we know that we will never have to suffer it.

Iñaki Rivera, who is familiar with the forces that maintain and promote prison, is well aware that the outlook is adverse and, despite the pessimism - that in this subject is also realism -, is not discouraged and shows us a possible and necessary way to contain mass imprisonment and thus take human rights seriously.

The book, I highlight, points out the existence of a possible and unavoidable path. It illustrates more than a hundred proposals, recommendations and alternatives for a public policy whose goal is decarceration. These are feasible proposals that seem to be the only possible way to respect international human rights law. This position of "radical guarantee" invites us to seriously take the fundamental rights of people deprived of their liberty and, on that basis, to define a programme of constant decarceration. Such proposal does not only mean respect for the human rights of prisoners, since by dehumanising such a person we also dehumanise ourselves, and massive dehumanisation necessarily means the dehumanisation of society. And this is just so, even if we are not aware of the pain of prisoners. Mass imprisonment, like a silent ghost, corrodes the freedom of all and ends up taking away the most precious thing of life itself.

On the other hand, the criminal effects that prison produces will be a price to be paid in the future and will translate into more crimes and higher levels of violence, which will also generate more prisons, more controls, more police and, in addition, more prisoners. In this way, mass incarceration, like an upward spiral, has as its point of arrival the confinement of all. Only a change of direction, a shift towards respect for human dignity, can help us avoid a suicidal policy. 


\section{Informações adicionais e declarações dos autores (integridade científica)}

Declaração de conflito de interesses (conflict of interest declaration): o autor confirma que não há conflitos de interesse na realização das pesquisas expostas e na redação desta resenha.

Declaração de autoria e especificação das contribuições (declaration of authorship): todas e somente as pessoas que atendem os requisitos de autoria desta resenha estão listadas como autores; todos os coautores se responsabilizam integralmente por este trabalho em sua totalidade.

Declaração de ineditismo e originalidade (declaration of originality): o autor assegura que o texto aqui publicado não foi divulgado anteriormente em outro meio e que futura republicação somente se realizará com a indicação expressa da referência desta publicação original; também atesta que não há plágio de terceiros ou autoplágio.

Dados do processo editorial

(http://www.ibraspp.com.br/revista/index.php/RBDPP/about/editorialPolicies)

- Recebido em: 22/01/2019

- Controle preliminar e verificação de plágio: 29/01/2019

- Deslocamento ao V5N2: 17/02/2019

- Decisão editorial preliminar e deslocamento ao V5N3: 23/05/2019

- Retorno rodada de correções: 29/09/2019

- Decisão editorial final: 30/09/2019
Equipe editorial envolvida

- Editor-chefe: 1 (VGV)

- Editor-associado: 1 (BC) 


\section{COMO CITAR ESTE ARTIGO:}

CUNEO, Silvio. Review: Rivera, Iñaki. Decarceration, principles for a public policy of reduction of the prison reduction (from a radical guarantism). Revista Brasileira de Direito Processual Penal, Porto Alegre, vol. 5, n. 3, p. 1681-1688, set./dez. 2019. https://doi.org/10.22197/rbdpp.v5i3.282

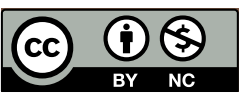

Esta obra está licenciada com uma Licença Creative Commons Atribuição-NãoComercial 4.0 Internacional. 